\title{
Institutional System of Watershed Management in Leitimor Peninsula, Ambon Island (Watershed Management Institution in Ambon Island Peninsula Leitimor)
}

\author{
Jusmy D. Putuhena ${ }^{1} \&$ Asep Sapei ${ }^{2}$ \\ ${ }^{1}$ Department of Forestry Faculty of Agriculture, University of Pattimura, Ambon, Indonesia \\ ${ }^{2}$ Bogor Agriculture Institute (IPB), Bogor, Indonesia \\ Correspondence: Jusmy D. Putuhena, Department of Forestry Faculty of Agriculture, University of Pattimura \\ Ambon, Indonesia. E-mail: jusmyputuhena@yahoo.com
}

Received: June 17, 2015

Accepted: June 28, 2015

Online Published: December 20, 2015

doi:10.5539/mas.v10n1p161

URL: http://dx.doi.org/10.5539/mas.v10n1p161

\begin{abstract}
Regional decentralization has made a change to any development sectors where a region (regency/town) holds a broader authority in managing natural resources, including watershed. Watershed management will run well if there is coordination and policy integration between the central and local government and between related institutions within a region. Relationship between institutions shall be always built on a coordination in order to prevent overlapping and conflict of interest in watershed management. The study aims to collect the data/information on main duties and functions of, authority of and roles of watershed management institution, especially the watershed in Ambon City, Leitimor Peninsula and to analyze them through stakeholder analysis approach. The findings found seventeen stakeholders who are in charge of the watershed management. Among those stakeholders, the primary and most important watershed managers are the Watershed Forum and forest farmer group.
\end{abstract}

Keywords: stakeholder, watershed management

\section{Introduction}

Watershed as one of ecosystem has an important role in water resources management. Outlined in the Law No. 7 of 2004 on Water Resources Management, watershed is an area of land which is a unit of ecosystem in the river and its tributaries that serves to accommodate, store and drain water from rainfall to the lake or the ocean naturally, which is the separation boundary on the land topography and sea boundary until the drainage area that is affected by land activities (Troch et al., 2009). Hobler et al. (2001) explains that watershed is an area of land which is the separation boundary on the ridge of mountains that accommodates and stores from rainfall and then drains the water to the ocean through the main stream (Hobler et al., 2001).

Watershed management is a process to formulate and implement activities, or a program to manipulate natural and human resources that exist in the watershed in purpose of gaining production and service advantages without making water and soil resources damaged. Watershed management shall take social, economic, culture and institutional aspects into consideration that operate out of and in the watershed concerned (Erickson et al., 2007).

Watershed management shall be carried out in integrative ways to improve coordination and synergism in the effort of conservation, utilization and destructive power control of water and also to serve the public water needs in sustainable time, space, quantity and quality (McMahon et al, 2013). In the context of water resources management, frequently arisen problems are too much water during rainy season causing flood and lack of water (dryness) during dry season (Oroud, 1998). Both problems are indicators of watershed damage that will finally have effect on unbalanced life, or further, on economic sector (Prabhakar et al., 2010).

Watershed management activity is often restricted to some political or administrative boundaries (state, province, regency). On the contrary, natural ecosystem limits are under-utilized, although natural disasters like flood and landslide do not care about political boundaries. Consequently, watershed problem solving does not work when the activities are conducted in apart under respective regional policy (Putuhena, 2014).

In the context of decentralization, natural resource in watershed is one of potential resources for the Regionally 
Generated Revenue escalation. Watershed management will work if there is coordination and policy integration between the central and local government, between related institutions in a region, and between the government, society and business world. A number of parties involved in the watershed ecosystem management have a consequence on the need of integrated management across sectors and culture (Liu, YB, Smedt, \& F, 2004).

Every element of resources, either physical or biotic (including human being), existing on earth's surface must be in a watershed. All parties, both the government-private institutions and society (individual alone or group) are concerned to the watershed management and utilization with different goals. The broader and more varied resources existing in a watershed, there will be more parties who are interested in the watershed (Putuhena et al., 2014).

The presence of many parties in watershed management highly destines sustainability of the watershed (Oroud, I. M., 2012). The roles of respective stakeholders in watershed management become an important matter for watershed conservation. If the watershed is well managed, society will get the benefits of land productivity improvement and water availability. The reality proves what has been stated by Citakoglu et al. (2014) that the upper and lower course of a watershed are connected to a hydrologic cycle, where land use activity has an effect on the change of occurred hydrologic process (Gleick \& PH, 1987; Alley \& W, 1984).

In Indonesia, critical watershed phenomena become serious environmental problems. In 1984, 22 watershed were on the list of critical status and this number was increasing up to 39 watershed in 1992, 42 watershed in 1998, 59 watershed in 2000 and 60 watershed in 2002, while Batu Merah watershed was one of the critical watershed on that list (Kartodiharjo \& Jhamtani, 2006). In 2005, the number of critical watershed in Indonesia increases up to 62 watershed, and in 2008, this number becomes 291 watershed (Kartodiharjo et al., 2004).

Goals of the study are to analyze participation of formal and informal institutions in watershed management and to decide which institution has important role as a leader for watershed management in Ambon City.

\section{Research Method}

\subsection{Research Site and Time}

The study is conducted in 2011 in Ambon City watershed region that covers Wai Ruhu watershed, Batu Merah watershed, Wai Tomu watershed, Batu Gajah watershed and Batu Gantung watershed at Leitimor Peninsula, Ambon Island of about 4,123.09 ha in area. The study on these five watershed is built on a reason that all these watershed are capable of supplying water resources for drinking water, minimum in Ambon City.

\subsection{Research Material and Equipments}

The materials required are administrative map, spatial zoning map, river network map and a list of questionnaires. The equipments in need to make the study swift are office stationary, survey instrument, block note and sound recorder.

\subsection{Data Collection Method}

Data collection is carried out through field orientation and interview to the institutions as the sample. The data collected includes main duties and functions of, organization structure of and authority of the institutions and also the activities they performed in relation with watershed management in Ambon City.

\subsection{Data Analysis}

Most of the collected data is unspecified that the analysis will be in descriptive qualitative, while the roles of institution will be analyzed by applying stakeholder analysis. The stakeholder analysis is initiated by placing the stakeholders into $2 \times 2$ matrix on the basis of stakeholder's interest on a problem and stakeholder's power over the problem (Maliva \& Missime, 2012).

\section{Findings and Discussion}

\subsection{General Overview of the Site}

Yearly rainfall in Ambon City watershed ranges from $1059 \mathrm{~mm}$ to $5693 \mathrm{~mm}$, and the average rainfall is $3015 \mathrm{~mm}$. Climate in Ambon City are tropical marine climate and seasonal climate because this city is surrounded by sea. Consequently, the climate is affected by seasonal climate in this region. Ambon City watershed is distinguished into six types of slopes: $0-3 \%, 3-8 \%, 8-15 \%, 15-35 \%, 35-45 \%$, and $>45 \%$ (Statistical of Ambon, 2012). The five types of slopes in this watershed are dominated by cliff/free face with the angle of $>45 \%$ by $3,206.22$ ha, crest $0-3 \%$ by 623.95 ha, talus slope $30-45 \%$ by 17.27 ha and bumpy to pediment slope with the angle of $15-30 \%$ by 26.08 ha. Podzolic type of soil covers an area around $1,738.98$ ha (44.21\%), alluvials cover 1085.33 ha (27.59\%), cambisols cover 859.24 ha (21.85\%) and lithosols cover around 249.74 ha (4.97\%). Land cover in 
2009 for secondary forest was $1,664.68$ ha, mixed dryland farming was 310.99 ha, open land was 66.60 ha, residential area was 498.12 ha, dryland farming was 141.45 ha and brushwood was 1,441.27 ha. Population in the research site in 2010 was 192,455 people with geographical density 46.68 people/ha.

\subsection{The Identification of Stakeholders}

Institutional study on watershed management is carried out based on the field observation toward the stakeholders in relevant with watershed management in Ambon City. The observation identifies 17 stakeholders who are interested in and have power over the integrated and sustainable watershed management in Ambon City (Table 41). The interview with stakeholders, then, is analyzed in descriptive and qualitative ways on the roles of respective institution.

Stakeholder analysis is conducted in purpose to find out interest/concern and roles of respective stakeholder and its power over watershed management. The success in solving a complicated problem in associated with many parties demands a clear understanding on the interest and relationship between stakeholders.

Basically, environmental management in Ambon City has been started since years ago through local institution in values of local wisdom called Sasi. Sasi is local wisdom in Maluku that presents in form of customary law. It functions to protect preservation of environment, such as prohibition against particular natural resource product taking in an effort of conserving the quality and population of biological resources. The sasi presenting in form of customary law aims to maintain former values and protect environment preservation that was developing since the 17 th century. Unfortunately, the sasi only plays a role in natural resource harvest time, but it does not ban the land use.

Table 1. The stakeholders and their involvement in Ambon City watershed management

\begin{tabular}{|c|c|c|}
\hline No & Stakeholders & Potential Roles \\
\hline 1. & $\begin{array}{l}\text { The Watershed Management Bureau Region XI } \\
\text { Wai Apo - Batu Merah Maluku }\end{array}$ & $\begin{array}{l}\text { Plans, monitors and evaluates watershed } \\
\text { management }\end{array}$ \\
\hline 2. & The Forestry Service of Maluku Province & Formulates forest policy across regencies \\
\hline 3. & The Forestry Service of Ambon City & Forest area planning and development \\
\hline 4. & $\begin{array}{l}\text { The Regional Development Planning Agency of } \\
\text { Ambon City }\end{array}$ & Macro planning and coordination of across sectors \\
\hline 5. & The Agricultural Service of Ambon City & Agricultural sector planning and development \\
\hline 6. & Balai Sungai for Region IV, Maluku & $\begin{array}{l}\text { Facilities and infrastructure planning and } \\
\text { development for surface water control }\end{array}$ \\
\hline 7. & $\begin{array}{l}\text { The Environmental Impact Management Agency, } \\
\text { Maluku Province }\end{array}$ & Environmental planning and controlling \\
\hline 8. & $\begin{array}{l}\text { The Environmental Impact Management Office of } \\
\text { Ambon City }\end{array}$ & Environmental planning and controlling \\
\hline 9. & The Public Works Service of Ambon CIty & $\begin{array}{l}\text { Facilities and infrastructure planning and } \\
\text { development }\end{array}$ \\
\hline 10. & The forum of watershed & Community counseling and empowerment \\
\hline 11. & The environmental village police officers & Plans, manages and monitors \\
\hline 12. & Colleges, such as Pattimura University & $\begin{array}{l}\text { Gives support by handing over the data, information } \\
\text { and scientific articles }\end{array}$ \\
\hline 13. & Nongovernmental organization & Community counseling and empowerment \\
\hline 14. & $\begin{array}{l}\text { Forest farmer group (Community } \text { Seedling } \\
\text { Nursery Kezia) }\end{array}$ & Directly involves in watershed management activity \\
\hline 15. & Synod of Protestant Church of Maluku & Community counseling and guidance \\
\hline 16 & Upstream community (farmer) & Gives support through green farming \\
\hline 17 & Regional Drinking Water Company & Supplies water for public \\
\hline
\end{tabular}

\subsection{The Stakeholder Analysis}

The analysis is initiated by placing the stakeholders into $2 \times 2$ matrix based on the stakeholder's interest on a 
problem and stakeholder's power on affecting the problem. What is meant by interest/concern attention is a stakeholder's concern or interest on watershed management (Hajkowicz, 2007). It is identifiable from the main duties and functions of respective institution. Power/authority, then, means stakeholder's power to have influence on or make decision or regulation concerning on the watershed management (Bojorquez Tapia et al., 2005). Figure 1 represents stakeholder analysis matrix as the manager of Ambon City watershed.

\section{$>$ Subject}

Subject is stakeholders who have great interest on the watershed, but they have minor influencing power. Several parties of these stakeholders are managing Ambon City watershed in earnest and better, even if they do not have any power to influence or make policy or regulation. Some stakeholders are put into the quadrant below.

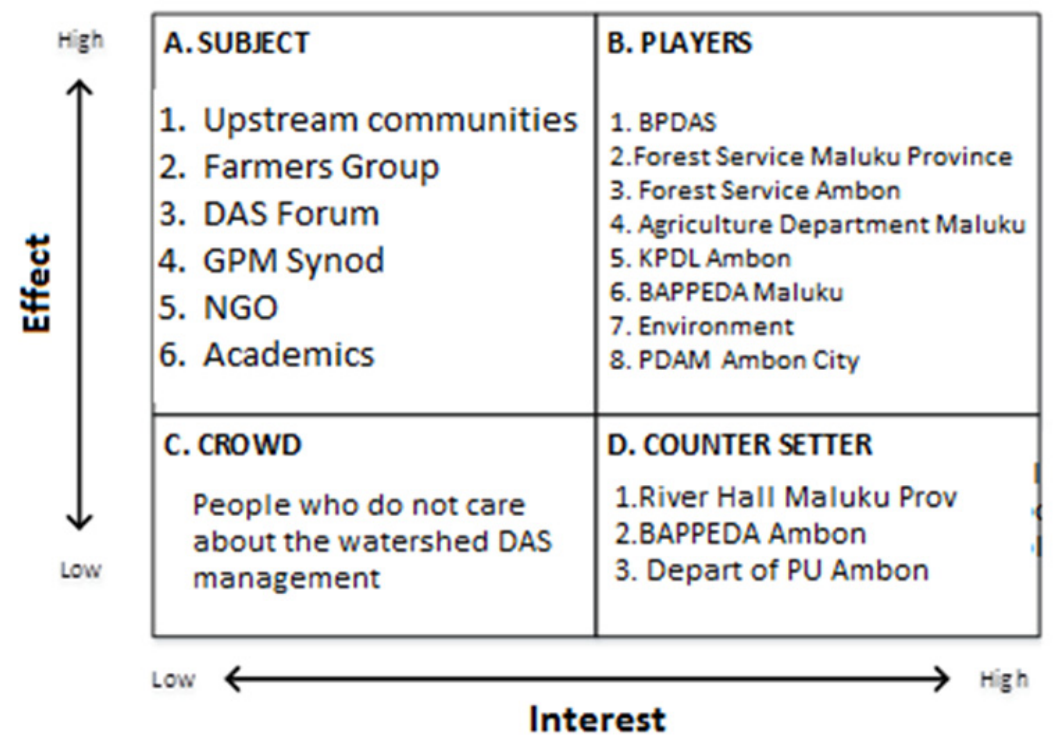

Figure 1. Stakeholders Matrix on Ambon City watershed management

\section{1) Upstream Community}

Community living in upstream area of watershed in Ambon City is interested in the watershed preservation. Their concern is triggered by intensive farming activity in marginal land. If the activities are carried out without any presence of land and water conservation technology, it will have negative effect on the lower land area. This upstream community is economically and socially dependent on the watershed of Ambon City.

2) The Forest Farmer Group (Community Seedling Nursery Kezia)

The forest farmer group (community seedling nursery) Kezia is a group of people established by the forum of watershed in purpose to manage the watershed by providing seedling, planting and growing up the seed. The farmer group's programs are considerably success up to now and applicable in the field.

3) The Forum of Watershed

The forum of watershed is established for one goal, a better watershed management. It implies that the forum has a concern on watershed management, including the watershed of Ambon City. However, the forum does not have any power to make a legal policy regarding a better watershed management in Ambon City. It has potential on community empowerment.

\section{4) The Synod of Protestant Church of Maluku}

This institution has an important role for community guidance and empowerment since the obedience of community (member of the congregation), in fact, on the ecclesiastic institution is higher than on the government or other institutions established by the government. Besides, there is an integrated program made by the synod of protestant church of Maluku concerning on environment management. Thus, collaboration between rehabilitation program and environment management run well. Unfortunately, this institution does not have an 
authority to make a legal policy for a better watershed management in Ambon City.

5) Nongovernmental Organization

It is community enterprise institution operating in social and environment sectors. This institution is functioned more as facilitator and colleague for the community living in Ambon City watershed. The institution has a function for coordination and cooperation with the government instiution in carrying out activities for environmental repair, especially watershed repair in Ambon City. However, this institution does not have any authority to make a legal policy for a better watershed management of Ambon City.

6) Academician

Academician has great concern and interest in Ambon City watershed preservation. The watershed preservation in Ambon City, for this institution, can be used as a learning source and a space to practice college student's lessons. Some researches have been conducted by lecturers and students in the watershed of Ambon City concerning on water quality, land use, land suitability, erosion, sedimentation, biodiversity and social-economic aspects of community. However, the institution does not have an authority to make a legal policy regarding a better watershed management in Ambon City.

\section{$>$ Players}

Players are stakeholders who have great interest and authority to the watershed. Player is meant to be a key organizer who is interested in and has a great influence on a better watershed management in Ambon City. Some steakeholders categorized in this quadrant are follows:

\section{1) The Watershed Management Bureau of Maluku}

The institution, based on its main duties and functions, specifically handles watershed management, especially in planning, monitoring and evaluation. It has influence on Ambon City watershed planning and development. On the other side, the watershed will affect the presence of Ambon City watershed. The Watershed Management Bureau is the center institution to implement the programs through cooperation with local services.

\section{2) The Forestry Service of Maluku Province}

It functions to handle problems of forest management. If the forest area surrounding the watershed is sufficient, it is capable of making ecological impact minimized on the watershed of Ambon City.

3) The Forestry Service of Ambon City

It may handle the problems of forest management in Ambon City. Regarding watershed management in Ambon City, the forestry service of Ambon City has an influence on the development of forest area existing in this region.

4) The Agricultural Service of Ambon City

It is interested in the watershed as it is an ecological, social and economic asset for the region. Accordingly, the watershed shall be protected for the continuity of public social-economic activities when the activity depends on the watershed of Ambon City. This institution has a power to formulate development policy that is environment-friendly for Ambon City watershed.

\section{5) The Environmental Impact Management Office of Ambon City}

This institution has a power to formulate policy on environment at local level of Ambon City. Besides, it also has interest in the watershed as an ecological asset. Thus, environment development in this area belongs to this institution's authority.

\section{6) The Environmental Impact Management Agency of Maluku Province}

The institution's interest is triggered by a fact that the watershed has ecological and social asset for the region. It has an interest to protect watershed ecosystem as a part of biodiversity. Besides, the institution has a power to formulate policy about the researches undertaken in the watershed, including to make a masterplan for Ambon City watershed.

\section{7) The Environmental Village Police Officers}

It is an extension of local government which was established downstream to the lowest level in government structure, and it involves traditional-law leaders in managing and protecting the watershed in Ambon City.

8) The Environmental Village Police Officers

It is an extension of Ambon City local government that serves to distribute clean water for domestic need 
accomplishment. It is authorized to formulate water use authority and masterplan for the watershed in Ambon City.

\section{$>$ Contest Setter}

Contest setter is stakeholders who have interest at a little portion, but great influence on the others. Contest setter in the watershed management of Ambon City is meant to be the stakeholders who function as macro planner for the development and coordination. Due to an extensive scope of work, the interest of institution in Ambon City watershed management is considered little. The vast influence of contest setter is affected by its power to legalize programs proposed by related institutions, including the authority in budget priority. It also has influence on the watershed sustainability, even it is at small portion. Some institutions are categorized as contest setter as follows.

\section{1) Balai Sungai for Maluku Region}

It has an influence relating to planning and construction for water management, such as river stream monitoring station to monitor water level in the rivers streaming down in the watershed of Ambon City. In the planning and implementation, Balai Sungai makes coordination with the technical institution, such as the Public Works of Ambon City and the Regional Development Planning Agency.

2) The Regional Development Planning Agency of Ambon City

It is an institution with main duties and functions to formulate technical procedures and then coordinate them with stakeholders at Ambon City level. It may influence the development planning, including what exists in the watershed of Ambon City.

3) The Public Works of Ambon City

It is authorized to provide facilities and infrastructure in Ambon City, including to make spatial zoning plan for Ambon City.

\section{$>$ Crowd}

Crowd is those people who has small portion of interest and power. In this box, community as the stakeholder is put into. Community in box of crowd is those people who have a small interest in watershed management.

\subsection{The Involvement and Relationship between Stakeholders in the Watershed Management}

The most stable institution in the watershed management of Ambon City is the Watershed Management Bureau Wae Hapu-Batu Merah, Maluku. It is set by a status of this institution that is internally very good with a proof of well-built human resources and fund sources from the National State Budget for watershed management. Bymeans of coordination and cooperation with vary institutions existing in Ambon City, rehabilitation in Ambon City watershed area will run well through the Forest and Land Rehabilitation activities. The Forest and Land Rehabilitation activity is limited to seed planting without providing any counseling and empowerment to community. Consequently, it becomes a constraint for land rehabilitation program continuity. The Forum of Watershed is an extension organization of the Watershed Management Bureau Wae Hapu-Batu Merah with its community counseling and empowerment functions in the watershed rehabilitation and conservation. It is proved by the establishment of school on field and forest farmer groups.

The forest farmer group (Community Seedling Nursery Kezia) established in the upstream of Ambon City watershed has an important role in the program implementation set by the Watershed Management Bureau Wae Hapu-Batu Merah and the Forestry Service and Agricultural Service of Ambon City as well in the land rehabilitation at the watershed conservation area of Ambon City. The Forest Farmer Group is trained to store water through training and cooperation with the Forum of Maluku Watershed and USAID (United States Agency International Development) in 2009. The subject matter covers a water resource area conservation action plan that involves many parties; water resource conservation zoning plan; analysis of water resource tendency and threat, and protection action plan.

Involvement of religious leaders, the synod of protestant church of Maluku in this case, is great to empower and invite the community (member of the congregation) to join with the watershed rehabilitation in Ambon City. Considering a fact that people of Ambon City hold tight their strong custom and culture, their respect for religious leaders is very high. In the program of the synod of protestant church of Maluku, it also concerns on environment cleanliness and natural resources conservation.

Programs of watershed area management in Ambon City shall be performed with the involvement of related institutions, i.e. 3 village administration pillars. The three pillars in Maluku traditional villages are called Tiga 
Tungku consisting of (a) the Government, represented by the King or Headman, (b) Religious leader, represented by Pastor/Religious Scholar, (c) Educator, represented by Headmaster of the schools existing in the village. If the three pillars of the village are invited by the government in any program, it makes certain that the success of program will be better.The relationship of watershed management institution is illustrated in Figure 2.

The Regional Drinking Water Company and DSA Inc. are in charge of supplying water to customer and ascertaining water need accomplishment. These two institutions also make coordination with the Watershed Management Bureau, relevant institutions and upstream community to protect and take care the upper course of watershed as water resource area, to evaluate and monitor the leakage in water supply pipe network or government institution. The Regional Drinking Water Company of Ambon City utilizes the existing surface water potential as long as it can to add water production for community's water need accomplishment.

Figure 2 illustrates the Watershed Management Bureau and related institutions with the Forum of Watershed in formulating work plan for watershed management. The Forum of Watershed also acts as a bridge for the government's upstream conservation program for Ambon City watershed in cooperation with the Forest Farmer Group (Community Seedling Nursery Kezia) as field executor. The program also gets support from the synod of protestant church of Maluku through public participation and support in order to execute the rehabilitation program for Ambon City watershed well.

Academician may directly participate in the watershed management through coordination with other stakeholders by providing the data collected from research findings that were carried out in the watershed of Ambon City. Purposely, the program for watershed conservation will be appropriate with the condition on site.

The implementation of watershed management program in Ambon City proposed to the stakeholders is made in the list of Table 2 below.

\section{Function and Role of Stakeholders}

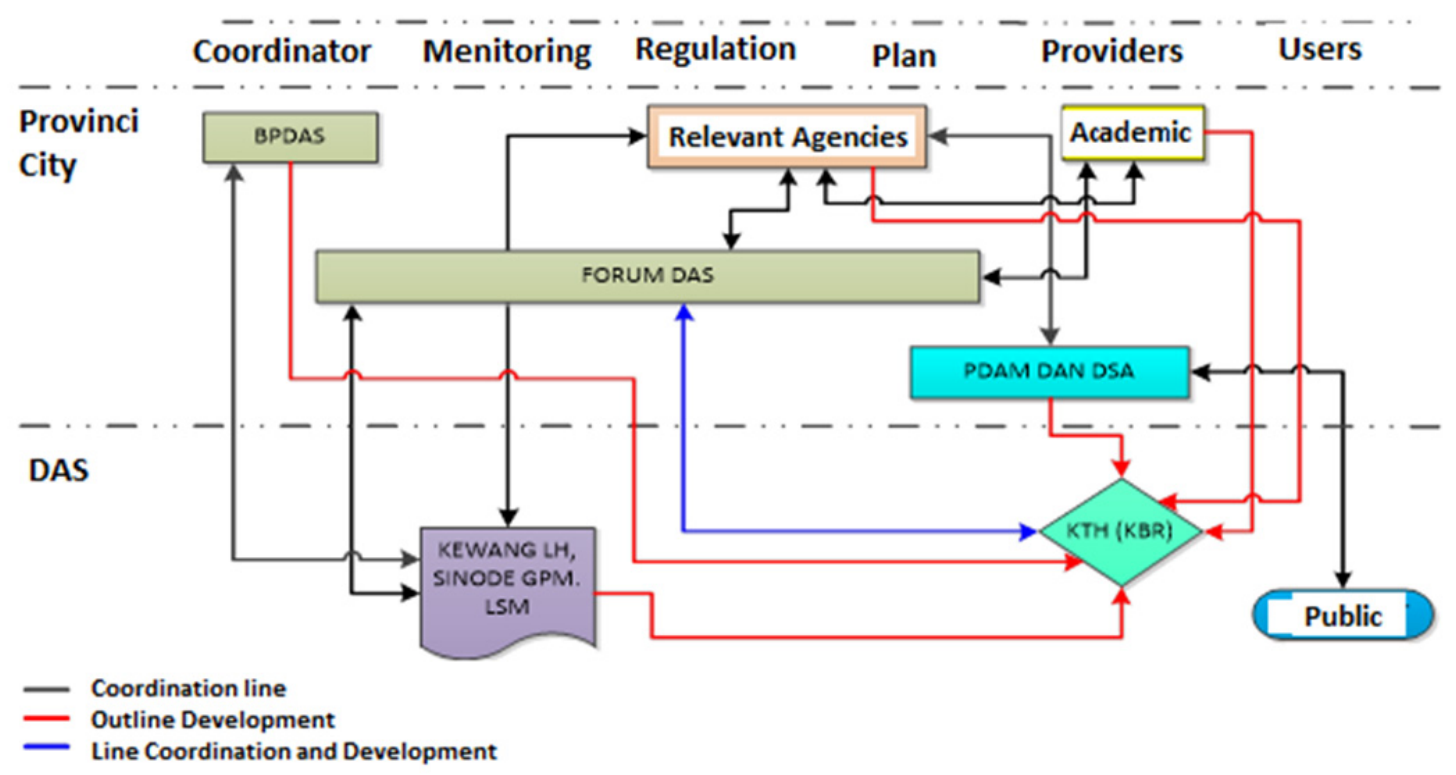

Figure 2. Flow chart of collaborative relationship between the stakeholders of watershed management to support water availability in Ambon City 
Table 2. The roles of stakeholders in Ambon City watershed management

\begin{tabular}{|c|c|c|c|c|}
\hline No. & $\begin{array}{c}\text { Sta } \\
\text { keholder } \\
\end{array}$ & & $\begin{array}{c}\text { The Roles of Stakeholders in Ambon City } \\
\text { Watershed Management }\end{array}$ & Constraint \\
\hline 1. & $\begin{array}{l}\text { The Watershed } \\
\text { Management } \\
\text { Bureau and Related } \\
\text { Institution }\end{array}$ & 3. & $\begin{array}{l}\text { Proposes regional regulation on forest width } \\
\text { adequacy in the watershed of Ambon City } \\
\text { Hampers a new Building Permit proposal in } \\
\text { the upstream area of watershed } \\
\text { Formulates the upstream conservation } \\
\text { program by inviting community in form of } \\
\text { collaboration. } \\
\text { Provides counseling and guidance to the } \\
\text { upstream community, in general, and the } \\
\text { Forest Farmer Group, in special. } \\
\text { Improves environmental data and information }\end{array}$ & $\begin{array}{l}\text { 1. Sector-based planning. } \\
\text { 2. Lack of regulation } \\
\text { enforcement. } \\
\text { 3. Lack of response in form of } \\
\text { political support from } \\
\text { legislative assembly. }\end{array}$ \\
\hline 2. & $\begin{array}{l}\text { The Forum of } \\
\text { Watershed }\end{array}$ & 1. & $\begin{array}{l}\text { Connects the government's program with the } \\
\text { Forest Farmer Group in form of decision on } \\
\text { plan of work and budget allocation as } \\
\text { prepared by the government. } \\
\text { Organizes training and guidance to the Forest } \\
\text { Farmer Group }\end{array}$ & $\begin{array}{l}\text { 1. Lack of meeting and } \\
\text { coordination } \\
\text { 2. Dependence on the available } \\
\text { budget }\end{array}$ \\
\hline 3. & $\begin{array}{l}\text { The Regional } \\
\text { Drinking Water } \\
\text { Company and DSA } \\
\text { Inc. }\end{array}$ & 1. & $\begin{array}{l}\text { Manages the water use and provides } \\
\text { infrastructure for domestic, industrial and } \\
\text { agricultural clean water system. } \\
\text { In cooperation with upstream community and } \\
\text { the Forest Farmer Group (Community } \\
\text { Seedling Nursery) to conserve the area } \\
\text { surrounding water resources. } \\
\text { Calls the people for water saving. }\end{array}$ & $\begin{array}{l}\text { 1. Declining discharge in the } \\
\text { water resources that also } \\
\text { declines the distribution of } \\
\text { clean water } \\
\text { 2. Lack of authority to restrict } \\
\text { land conversion surrounding } \\
\text { upstream area. } \\
\text { 3. Weak management }\end{array}$ \\
\hline 4. & $\begin{array}{l}\text { The environmental } \\
\text { village police } \\
\text { officers, the synod } \\
\text { of protestant church } \\
\text { of Maluku, and } \\
\text { nongovernmental } \\
\text { organization. }\end{array}$ & $\begin{array}{l}2 . \\
3 . \\
4 .\end{array}$ & $\begin{array}{l}\text { Provides counseling and guidance to the } \\
\text { upstream community and the Forest Farmer } \\
\text { Group (Community Seedling Nursery) } \\
\text { concerning on the importance of watershed } \\
\text { conservation. } \\
\text { Captures public aspiration about watershed } \\
\text { conservation. } \\
\text { Participates straightaway in the watershed } \\
\text { conservation program. }\end{array}$ & $\begin{array}{l}\text { Does not have any authority in } \\
\text { decision making. }\end{array}$ \\
\hline 5. & $\begin{array}{l}\text { The Forest Farmer } \\
\text { Group (Community } \\
\text { Seedling Nursery) }\end{array}$ & $\begin{array}{l}1 . \\
2 . \\
3 .\end{array}$ & $\begin{array}{l}\text { Provides land for forest and land } \\
\text { rehabilitation activity. } \\
\text { Prepares member of group, supplies the seed, } \\
\text { plants and grows up the seed. } \\
\text { Develops the action plan for biodiversity } \\
\text { conservation and utilizes non-wood forest } \\
\text { function and improves the forest security } \\
\text { system. } \\
\text { Develops conservative agricultural pattern }\end{array}$ & $\begin{array}{l}\text { 1. Depends on the budget and } \\
\text { utilizes the fund for } \\
\text { rehabilitation and } \\
\text { conservation program. } \\
\text { 2. Lack of awareness, training } \\
\text { and counseling from the } \\
\text { related institution concerning } \\
\text { on watershed conservation. }\end{array}$ \\
\hline 6. & Academician & 1. & $\begin{array}{l}\text { Carries out studies on the local condition at } \\
\text { which the findings will be used as } \\
\text { consideration basis for watershed } \\
\text { conservation program implementation. } \\
\text { Directly involves in upper course of the } \\
\text { watershed conservation activity }\end{array}$ & Lack of fund for research. \\
\hline 7. & Community & & $\begin{array}{l}\text { Consumes clean water to the needs and be } \\
\text { water-saving. } \\
\text { Be obedient and consistent to the established } \\
\text { duties }\end{array}$ & $\begin{array}{l}\text { 1. Lack of awareness on the } \\
\text { importance of conservation } \\
\text { 2. Depends on water service } \\
\text { providers. }\end{array}$ \\
\hline
\end{tabular}


To be convinced, stakeholder who has important roles to support water resources sustainability in Ambon City are upstream community, in general, and specifically it is represented by the Forest Farmer Group (Community Seedling Nursery). The Forest Farmer Group plays the role to protect the upper course of watershed in order to maintain hydrological function. Another important stakeholder is the Regional Drinking Water Company and DSA Inc. who are in charge of supplying water for public. These two stakeholders can function well if they are supported by other stakeholders as mentioned in Table 2 and Figure 2. If all elements of institution in the Figure 2 above work together, the watershed preservation in Ambon City will be protected and sustainable. Indication of water sustainability is when water in the watershed is available and can be streamed down all year round even if the volume rate of water flow is low.

\section{Conclusion and Suggestion}

\subsection{Conclusion}

1) There are 17 stakeholders who are involved in the watershed management of Ambon City. They are put into quadrants of contest setter, player and subject in the matrix of power versus interest grids. The institutionalism of watershed management in Ambon City is quite stable where the existing human resources is good and the function of coordination works well.

2) Stakeholder having important roles in the watershed management of Ambon City is the Forum of Watershed of Maluku as it is an extension of the government and the Forest Farmer Group as the executor on field.

\subsection{Suggestion}

In the context of well-built watershed management in Ambon City, the institutionalism of watershed management shall be improved in its performance, and the local government through relevant institutions shall provide intensive counseling and guidance to the watershed management institution.

\section{References}

Alley, W. (1984). On the treatment of evapotranspiration, soil moisture accounting and aquifer recharge in monthly water balance models. Water Resour Res, 20, 1137-1149.

Bojorquez Tapia, L. A., Sanchez Colon, S., \& Martinez, A. F. (2005). Building consensus in environmental impact assessment through multicriteria modeling and sensitivity analysis. Environmental Management, 36(3), 469-481.

Citakoglu, H., Cobaner, M., Aktanir, T., \& Kisi, O. (2014). Estimation of monthly mean reference evapotranspiration in Turkey. Water Resour Manag, 28, 99-113.

Erickson, J. D., Messner, F. I., \& Ring, eds. (2007). Ecological Economics of Sustainable Watershed Management. Elsevier, Amsterdam. The Netherlands.

Gleick, P. H. (1987). Regional hydrologic consequences of increases in atmospheric carbon dioxide and other trace gases. Clim Chang, 10, 137-161.

Hajkowicz, S. A. (2007). Supporting multi-stakeholder environmental decision. Journal of Environmental Management, 88(2008), 607-614. Retrieved from http://www.elsevier.com/locate/jenvman

Hobler, M., Margane, A., Almomani, M., \& Subah, A. (2001). Contributions to the hydrogeology of Northern Jordan. Ministry of Water and Irrigation (MWI) and Federal Institute for Geosciences and Natural Resources (BGR). Ground Water Resources of Northern Jordan, 4.

Kartodiharjo, H., \& Jhamtani, H. (2006). Environmental Politics and Power in Indonesia. First mold. Equinox Publishing Indonesia, Jakarta.

Kartodiharjo, H., Murtilaksono, K., \& Sudadi, U. (2004). Watershed Management Institution. Concept and Introduction. Faculty of Forestry, Bogor Agricultural University.

Liu, Y. B., \& Smedt, F. (2004). A GIS-based hydrological model for flood prediction and watershed management (documentation and user manual). Dept. Hydrology and Hydraulic Engineering, Vrije Univ, Brussel.

Maliva, R., \& Missimer, T. (2012). Recharge measurement in arid and semiarid regions, arid lands water evaluation and management: Environmental science and engineering. Springer, Heidelberg.

McMahon, T., Peel, M., Lowe, L., Srikanthan, R., \& Mc Vicar, T. (2013). Estimating actual, potential, reference crop and pan evaporation using standard meteorological data: a pragmatic synthesis. Hydrol Earth Syst Sci., 17, 1331-1363.

Oroud, I. M. (1998). The influence of heat conduction on evaporation from sunken pans in hot, dry environments. 
J Hydrol, 210, 1-10.

Oroud, I. M. (2012). Climate change impact on green water fluxes in the eastern Mediterranean. In Leal Filho, W. (Ed.), Climate change and the sustainable management of water resources, (pp. 3-15), Springer. http://dx.doi.org/10.1007/978-3-642-22266-5

Prabhakar, K., Lavanya, K., \& Papa Rao, A. (2010). NGOs and Farmers Participation in Watershed Development Programme in Prakasam District. Asia-Pacific Journal of Social Science, 2(1), 173-182.

Putuhena, J. D., Sapei, A., Purwanto, M. T. J., \& Prasetyo, L. B. (2014). Sustainable Water Supply Model in Ambon Island. Journal of Environment and Ecology, 5(2).

Troch, P., Martinez, F., Pauwels, V., Durcik, M., Sivapalan, M., Harman, ... Huxman, T. (2009). Climate and vegetation water use efficiency at catchment scales. Hydrol Process, 23, 2409-2414.

\section{Copyrights}

Copyright for this article is retained by the author(s), with first publication rights granted to the journal.

This is an open-access article distributed under the terms and conditions of the Creative Commons Attribution license (http://creativecommons.org/licenses/by/3.0/). 